\title{
Chemical and Optical Properties of Atmospheric Aerosols during the Polluted Periods in a Megacity in the Yangtze River Delta, China
}

\author{
Xingna Yu ${ }^{1,2^{*}}$, Li Shen ${ }^{1}$, Sihan Xiao ${ }^{1}, J_{i a} \mathrm{Ma}^{3}$, Rui L $\ddot{u}^{1}$, Bin $\mathrm{Zhu}^{1}$, Jianlin Hu${ }^{4}$, Kui Chen ${ }^{1}$, \\ Jun $\mathrm{Zhu}^{1}$ \\ ${ }^{I}$ Key Laboratory of Meteorological Disaster, Ministry of Education (KLME)/Joint International Research Laboratory of \\ Climate and Environment Change (ILCEC)/Collaborative Innovation Center on Forecast and Evaluation of \\ Meteorological Disasters (CIC-FEMD)/Key Laboratory for Aerosol-Cloud-Precipitation of China Meteorological \\ Administration, Nanjing University of Information Science and Technology, Nanjing 210044, China \\ ${ }^{2}$ Shanghai Key Laboratory of Atmospheric Particle Pollution and Prevention (LAP ${ }^{3}$ ), Shanghai 200433, China \\ ${ }^{3}$ Guangzhou Hexin Analytical Instrument Company Limited, Guangzhou 510530, China \\ ${ }^{4}$ Collaborative Innovation Center of Atmospheric Environment and Equipment Technology, Jiangsu Key Laboratory of \\ Atmospheric Environment Monitoring and Pollution Control, School of Environmental Science and Engineering, Nanjing \\ University of Information Science and Technology, Nanjing 210044, China
}

\begin{abstract}
The chemical composition and optical properties of particulate matter (PM) were characterized in an urban-industrial area of Nanjing, China, in January 2015, when heavily polluted periods frequently occurred. Only $30 \%$ of the days fulfilled the National Ambient Air Quality Standards of China. The average scattering and absorption coefficients at 532 $\mathrm{nm}$ during the polluted periods were $620 \pm 320 \mathrm{Mm}^{-1}$ and $102 \pm 57 \mathrm{Mm}^{-1}$. An increasing relative fraction of the large size PM during the polluted periods can be deduced from the variations of the scattering Angström exponent, backscattering ratio, and asymmetry factor. The mean mass concentrations of $\mathrm{NO}_{3}{ }^{-}, \mathrm{SO}_{4}{ }^{2-}$ and $\mathrm{NH}_{4}{ }^{+}$in $\mathrm{PM}_{2.5}$ during the polluted periods were $32.87 \pm 17.76 \mu \mathrm{g} \mathrm{m}^{-3}, 23.6 \pm 13.2 \mu \mathrm{g} \mathrm{m}^{-3}$, and $19.4 \pm 10.1 \mu \mathrm{g} \mathrm{m}^{-3}$, respectively. $\mathrm{NO}_{3}^{-}, \mathrm{SO}_{4}{ }^{2-}$ and $\mathrm{NH}_{4}^{+}$were the dominant water-soluble ions (WSIs) and accounted for $87 \%$ of the total ion concentration. Nitrate and organic matter (OM) dominated the aerosol composition during the polluted periods. The averaged organic carbon/elementary carbon ratios during the polluted and the cleaner periods were 3.6 and 4.3, respectively, consistent with a mix of primary emissions and secondary organic aerosol formation. Organic matter and ammonium nitrate (AN) were the dominant species contributing to light extinction during the polluted periods, contributing values of $159 \pm 63 \mathrm{Mm}^{-1}$ and $156 \pm 91 \mathrm{Mm}^{-1}$, respectively.
\end{abstract}

Keywords: Air pollution; Aerosol chemical composition; Aerosol optical properties; Atmospheric extinction.

\section{INTRODUCTION}

Atmospheric aerosols play a significant role in radiation balance and radiative forcing by directly interacting with solar radiation and by indirectly influencing the formation, optical properties and lifetime of clouds by acting as cloud condensation nuclei (Li et al., 2011; Ramanathan et al., 2001). In addition, elevated atmospheric aerosols cause visibility impairment and adverse health effects (Zhou et al., 2014; Yu et al., 2016a). However, quantification of these effects still contains large uncertainties, mainly due to poor

\footnotetext{
* Corresponding author.

Tel.: +86-25-5873159

E-mail address: xnyu@nuist.edu.cn
}

understanding of aerosol physicochemical properties and their heterogeneous temporal and spatial variation.

The Yangtze River Delta (YRD) is regarded as one of the major haze regions in China, and has been experiencing high concentrations of fine particulate matter $\left(\mathrm{PM}_{2.5}\right)$ and low visual ranges (Che et al., 2007; Gao et al., 2011; Shen et al., 2015; Zhang et al., 2017). Nanjing, the provincial capital of Jiangsu Province with over 8 million inhabitants, has been suffering heavy haze pollution which is caused by large emissions from complex sources including automobiles, coal-fired power plants, electronics, petrochemical and steel industries, etc. The concentration levels of $\mathrm{PM}_{2.5}$ and the numbers of haze days have been increasing. For example, the number of haze days in Nanjing was over 130 days during 2001-2006 (Dong et al., 2007; Qian et al., 2008), and increased to more than 161 days between 2008 and 2010 (Lin et al., 2012). The average mass concentration of 
$\mathrm{PM}_{2.5}$ reached $113 \pm 69 \mu \mathrm{g} \mathrm{m}^{-3}$ and average visibility was $4.8 \pm 3.2 \mathrm{~km}$ during haze pollution in the winter of 2014 (Kong et al., 2015). In recent years, many studies have been carried out in this area mainly focusing on aerosol chemical composition, source apportionment, new particle formation and optical properties based on long-term or short-term ground-based or satellite remote sensing data (Duan et al., 2006; Shen et al., 2009; Tan et al., 2009; An et al., 2015; Wang et al., 2015; Xu et al., 2015; Qi et al., 2016; Yu et al., 2016; Wang et al., 2016b; Du et al., 2017). However, the comprehensive understanding of aerosol optical and chemical properties during high pollution days remains unknown for this area. Specifically, a quantitative relationship between visibility impairment and aerosol chemical components, which are very valuable for designing effective pollutant control policies to improve impaired visibility condition, is far from complete. In this study, we measured the water-soluble ions (WSIs) and carbonaceous compounds in $\mathrm{PM}_{2.5}$ during polluted and cleaner periods in a winter season. We also analyzed the aerosol scattering and absorption coefficients, and derived backscattering ratio, asymmetry factor, scattering Ångström exponent and mass scattering efficiency. Finally, we examined the relative contribution of chemical components in $\mathrm{PM}_{2.5}$ to visibility degradation using the IMPROVE (Interagency Monitoring of Protected Visual Environments) algorithm (Malm et al., 1994).

\section{INSTRUMENTATION AND METHODOLOGY}

\section{Site and Sampling}

All the surface observations of aerosol chemical and optical properties presented in this study were conducted at an urban-industrial site of Nanjing in Luhe District, which is about $5 \mathrm{~km}$ from the observation site located in the north of Nanjing, and is also an important production base of the steel industry. The pollution sources in this area are mainly emissions from industries, traffic and urban construction activities (Wang et al., 2014). The measurements were performed on the roof of the Meteorology Building about $30 \mathrm{~m}$ above ground level on the Nanjing University of Information Science and Technology (NUIST) campus (lat: $32.2^{\circ} \mathrm{N}$, long: $118.7^{\circ} \mathrm{E}$ ). The meteorological data were recorded by different weather sensors mounted on the automatic weather station (AWS) and the visibility data were obtained from a forward scattering visibility meter (Model: CJY-1A) installed in the campus, which is $\sim 800 \mathrm{~m}$ from the experimental site. The pollution sources surrounding the observation site include the Nanjing chemical industry factories situated $\sim 3 \mathrm{~km}$ to the southwest, iron and steel plants within $2 \mathrm{~km}$ vicinity of site to the northwest and main traffic roads within $500 \mathrm{~m}$ (see Fig. 1).

Sampling was normally conducted once every 6 hours starting at 3:00 AM Beijing Time. $\mathrm{PM}_{2.5}$ samples were collected at a flow rate of $100 \mathrm{~L} \mathrm{~min}^{-1}$ with a $\mathrm{KC}-120 \mathrm{H}$ QingDaoLaoshan sampler (Laoshan Electronic Instrument Factory Co., LTD., QingDao, China). Samples were collected on $90 \mathrm{~mm}$ Whatman quartz fiber filters (QM-A ${ }^{\mathrm{TM}}$, Whatman, Clifton, NJ, USA) from 8 January to 31 January 2015. The filters were pre-baked by heating at $800^{\circ} \mathrm{C}$ for $5 \mathrm{~h}$ to remove residual carbon. After sampling, the filters were transported in a portable cooler to the aerosol laboratory to minimize loss of volatile compounds. Field blank filters were also collected periodically by exposing filters in the sampler without drawing air through them; these were used to account for any artifacts introduced during the sample handling process.

Measurements of half-hourly $\mathrm{PM}_{1}$ and $\mathrm{PM}_{2.5}$ were conducted using two Thermo Fisher Scientific FH62C14 beta attenuation instruments equipped with $1.0 \mu \mathrm{m}$ and $2.5 \mu \mathrm{m}$ cut-points, respectively.

\section{Chemical and Optical Analysis}

Organic Carbon (OC) and Elemental Carbon (EC) Analysis A $0.5 \mathrm{~cm}^{2}$ punch from each quartz filter was analyzed for OC and EC by using a Desert Research Institute Model 2001 thermal/optical carbon analyzer (Atmoslytic Inc., Calabasas, CA, USA). Detailed information of the method, including quality assurance/quality control (QA/QC) procedures, is described by Wang et al. (2014).

\section{Water-Soluble Inorganic Ions Analysis}

A quarter portion of filter was used to determine the WSIs. WSIs were analyzed using a Model 850 professional Ion Chromatography (IC) system (Metrohm, Switzerland). The chromatography system includes a column oven, conductivity detector, a model 858 auto-injector and MagIC Net chromatography workstation (Metrohm, Switzerland); Column; Metrosep C 4150/4.0 separation column and Metrosep A Supp 5150/4.0 separation column; eluent: $3.2 \mathrm{mmol} \mathrm{L}^{-1} \mathrm{Na}_{2} \mathrm{CO}_{3}+1.0 \mathrm{mmol} \mathrm{L} \mathrm{NaHCO}_{3}$ (anions), $1.7 \mathrm{mmol} \mathrm{L}^{-1} \mathrm{HNO}_{3}+0.7 \mathrm{mmol} \mathrm{L}^{-1}$ pyridine carboxylic acid (cations); column temperature: $30^{\circ} \mathrm{C}$; flow-rate:

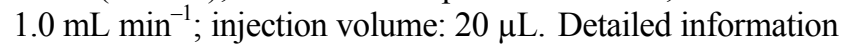
is available from Li et al. (2014).

\section{Scattering and Absorption Coefficients}

The total scattering $\left(\sigma_{\mathrm{sp}} ; 7-170^{\circ}\right.$ angular integration $)$ and hemispheric back scattering $\left(\sigma_{\text {bsp }} ; 90-170^{\circ}\right)$ coefficients at the wavelengths of 450, 550 and $700 \mathrm{~nm}$ were measured with an Integrating Nephelometer (Model 3563, TSI, USA). An inverted funnel with screws was fitted at the entrance of the instrument to avoid dust, rainwater, and insects entering into the system. This instrument draws the ambient air through stainless steel tubing at a fixed flow rate of $20 \mathrm{~L} \mathrm{~min}^{-1}$ without aerosol size cut-off. The samples were illuminated with a halogen lamp and measures scattered light at the above three wavelengths using three photomultiplier tubes. Calibration of the nephelometer was carried out before the experiments with filtered air as a low span gas and carbon dioxide $\left(\mathrm{CO}_{2}\right.$, purity: $\left.99.99 \%\right)$ as the high span gas. The total scattering and backscattering coefficients were corrected on a systematic basis considering the angular truncation correction method proposed by Anderson and Ogren (Anderson et al., 1998) and Sherman et al. (2015). The instrument calibration, error estimation and uncertainty have been presented elsewhere (Fan et al., 2010; Esteve et al., 2012; Jing et al., 2015). 


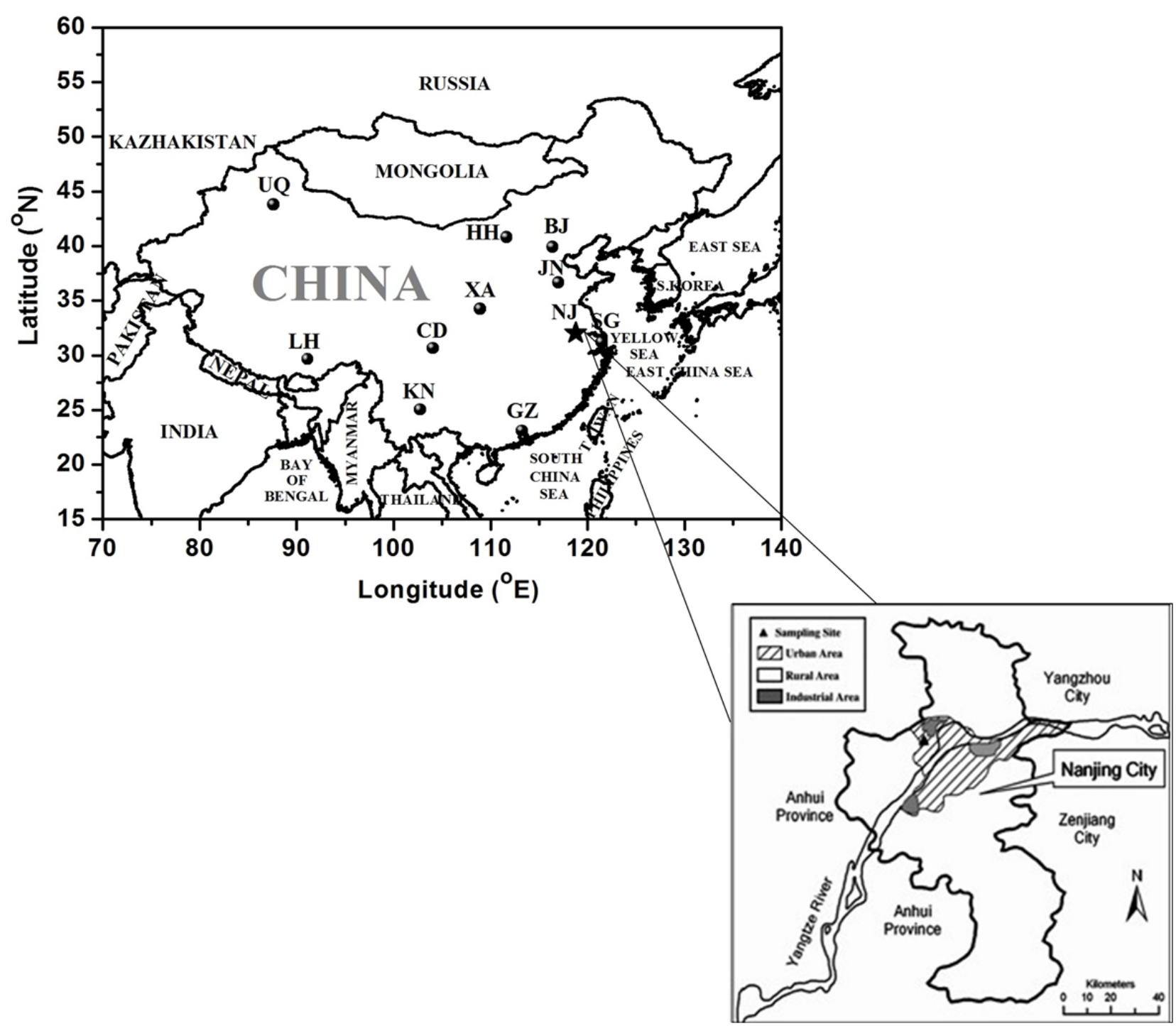

Fig. 1. Geographical location of Nanjing (NJ) over China represented with a solid star symbol along with its bordering countries and oceans. Also shown is the location of NJ urban-industrial area indicated with a triangle in the Yangtze River Delta (YRD) with its major sources in the vicinity of the sampling site.

The scattering coefficient is greatly affected by relative humidity $(\mathrm{RH})$, which shows a negligible variation when $\mathrm{RH}<50 \%$ and a steep rise when $\mathrm{RH}>80 \%$ (Anderson et al., 1998). In this study, sample air enters the inlet through a protective cover to eliminate rain and insects then passes through a cyclone. After passing through the cyclone, the sample enters the top section of the inlet where its humidity is reduced with Perma Pure tubes. The Perma Pure diffusion drying tube, used to control sample RH, consists of an inner tube of Nafion through which the aerosol sample flows and an outer tube of stainless steel through which purge air flows. The inlet was always operated dry $(\mathrm{RH}<30 \%)$ with nephelometer measuring the dry scattering coefficient.

Aerosol absorption coefficient was measured using a 7channel aethalometer (Model AE-33, Magee Scientific, USA) at wavelengths of $370,470,520,590,660,880$, and $950 \mathrm{~nm}$ with a $\mathrm{PM}_{2.5}$ size cut. This instrument yielded a change in optical attenuation by measuring the intensity of the light beam passing through a filter tape. The air inlet is located $\sim 2 \mathrm{~m}$ above the roof. Routine flow calibration and blank sample test were implemented before sampling. The aethalometer was operated at a flow rate of $5.0 \mathrm{~L} \mathrm{~min}^{-1}$ in an automated mode and a sampling interval of $1 \mathrm{~min}$, under which the filter tape was forward when the attenuation at wavelength of $370 \mathrm{~nm}$ reached 75 .

\section{Data Treatment}

Calculation of Aerosol Absorption Coefficient $\left(\sigma_{a b s}\right)$ and the Aethalometer Model

Coen et al. (2010) and Weingartner et al. (2003) correction algorithms were selected for this study and the $\sigma_{\mathrm{abs}}$ has been estimated using the aethalometer data at all wavelengths.

$\sigma_{a b s}(\lambda)=\frac{B C \times 14625 \times 10^{-3}}{\lambda \times C \times R}$ 
where $\lambda$ is the wavelength (in $\mu \mathrm{m}$ ), $C$ and $R$ are correction factors for minimizing the inherent uncertainty associated with the aethalometer, resulting from multiple scattering of light in the filter matrix and the change in the optical path length due to successive aerosol loadings. The corrections for these uncertainties were completed following the results reported in Drinovec et al. (2015) by incorporating values of $R=1$ and $C=1.57$ for the multiple scattering corrections and loading effect, respectively.

The aethalometer model is designed to quantify the contribution of fossil fuel $\left(\mathrm{BC}_{\mathrm{ff}}\right)$ and biomass burning $\left(\mathrm{BC}_{\mathrm{bb}}\right)$ to the total $\mathrm{BC}$ concentration. It is based on the assumptions that the fossil fuel and biomass burning are the primary contributors of carbonaceous aerosols and the light absorption of aerosol by these two sources can be modelled (Herich et al., 2011). The dependence of aerosol light absorption on wavelength is parameterized using a power law relationship:

$\sigma_{a b s}(\lambda)=K \lambda^{\alpha_{a p}}$

where $\sigma_{\mathrm{abs}}$ is the spectrally dependent mass absorption coefficient, $\lambda$ the light wavelength, $K$ is a constant and $\alpha_{\text {ap }}$ is the absorption Ångström exponent. Higher $\alpha_{\mathrm{ap}}$ values were observed when aerosols are originating from biomass burning, as the spectral absorption of these species increases more rapidly at shorter wavelengths (Sandradewi et al., 2008). According to the study by Kirchstetter et al. (2004), $\alpha_{\mathrm{ff}}=1$ and $\alpha_{\mathrm{bb}}=2$ are used in this study. $\alpha_{\mathrm{ff}}$ and $\alpha_{\mathrm{bb}}$ are absorption Ångström exponents for fossil fuel and biomass burning emissions, respectively. The values for $\alpha_{\mathrm{ff}}$ and $\alpha_{\mathrm{bb}}$ are just estimates. $\sigma_{\mathrm{abs}}$ for the two component aerosol system can be represented as:

$\sigma_{\mathrm{abs}}(\lambda)=\sigma_{\mathrm{abs}}(\lambda)_{\mathrm{ff}}+\sigma_{\mathrm{abs}}(\lambda)_{\mathrm{bb}}$

$\sigma_{\mathrm{abs}}(\lambda)_{\mathrm{ff}}$ and $\sigma_{\mathrm{abs}}(\lambda)_{\mathrm{bb}}$ are the aerosol absorption coefficient of $\mathrm{BC}$ from fossil fuel and biomass burning emissions at wavelength $\lambda$, respectively.

Then, $\mathrm{BC}_{\mathrm{ff}}$ and $\mathrm{BC}_{\mathrm{bb}}$ can be calculated by Eqs. (3)-(7):

$\frac{\sigma_{\mathrm{abs}}(371)_{\mathrm{ff}}}{\sigma_{\mathrm{abs}}(880)_{\mathrm{ff}}}=\left(\frac{370}{880}\right)^{-\alpha_{\mathrm{ff}}}$

$\frac{\sigma_{\mathrm{abs}}(370)_{\mathrm{bb}}}{\sigma_{\mathrm{abs}}(880)_{\mathrm{bb}}}=\left(\frac{370}{880}\right)^{-\alpha_{\mathrm{bb}}}$

$\mathrm{BC}_{\mathrm{ff}}=\mathrm{BC} \frac{\sigma_{\mathrm{abs}}(880)_{\mathrm{ff}}}{\sigma_{\mathrm{abs}}(880)}$

$\mathrm{BC}=\mathrm{BC}_{\mathrm{ff}}+\mathrm{BC}_{\mathrm{bb}}$

\section{Calculation of Scattering Angström Exponent $(\alpha)$}

The nephelometer has three working wavelengths, but none of them matches the $532 \mathrm{~nm}$ working wavelength of the AE33. So, we selected the scattering coefficients measured at $550 \mathrm{~nm}\left(\sigma_{s p}(550 \mathrm{~nm})\right)$ and converted them to $532 \mathrm{~nm}\left(\sigma_{s p}(532 \mathrm{~nm})\right)$ to match with the $\sigma_{a p}(532 \mathrm{~nm})$ following the method adopted by Jung et al. (2010):

$$
\sigma_{s p}(532 \mathrm{~nm})=\sigma_{s p}(550 \mathrm{~nm}) \times\left[\frac{\lambda(532 \mathrm{~nm})}{\lambda(550 \mathrm{~nm})}\right]^{-\alpha}
$$

where ' $\alpha$ ' is the scattering Ångström exponent which is determined by the formula given below.

$$
\alpha=\frac{\log \left(\sigma_{s p}(700 \mathrm{~nm})\right)-\log \left(\sigma_{s p}(450 \mathrm{~nm})\right)}{\log (700 \mathrm{~nm})-\log (450 \mathrm{~nm})}
$$

\section{Calculation of Mass Scattering Efficiency (MSE)}

The mass scattering efficiency can be estimated by dividing the scattering coefficient by aerosol mass concentration. In this study, MSE was estimated as the ratio of $\sigma_{s p}(550 \mathrm{~nm})$ to $\mathrm{PM}_{2.5}$ mass concentration.

$$
M S E=\frac{\sigma_{s p}^{550}}{\mathrm{PM}_{2.5}}
$$

\section{Calculation of Backscattering Ratio and Asymmetry \\ Parameter $\left(g_{\lambda}\right)$}

The backscattering ratio $\left(b_{\lambda}\right)$ is the ratio of the hemispheric backscattering coefficient to the total scattering coefficient at a given wavelength.

$b_{\lambda}=\frac{\sigma_{b s p}^{\lambda}}{\sigma_{s p}^{\lambda}}$

The asymmetry parameter $\left(g_{\lambda}\right)$ is calculated from the backscattering ratio.

$g_{\lambda}=(-7.143889) b_{\lambda}^{3}+(7.46443) b_{\lambda}^{2}+(-3.9356) b_{\lambda}+0.9893$

where $g_{\lambda}$ and $b_{\lambda}$ obtained at the same wavelength. The above equation was suggested by Andrews et al. (2006) based on the plot of Wiscombe and Grams (1976) following the Henyey-Greenstein approximation for the asymmetry parameter. $g_{\lambda}$ measures the preferred scattering direction (forward or backward) for the light encountering the aerosol particles.

\section{Estimation of Chemical Extinction Coefficient $\left(b_{\text {ext }}\right)$}

Visibility degradation occurs as a result of the scattering and absorption of light by particles and gases in the atmosphere. $b_{\text {ext }}$ is estimated according to the IMPROVE program formula as described by Malm et al. (1994),

$b_{\text {ext }} \approx 3 f(\mathrm{RH}) \times[$ ammonium sulfate $]+3 f(\mathrm{RH}) \times$ [ammonium nitrate $]+4 \times[$ Organic matter $]+1 \times[$ Soil $]+10$ $\times[\mathrm{EC}]+0.6 \times[$ coarse mass $]+$ Rayleigh Scattering

where the unit of $b_{\text {ext }}$ is $\mathrm{Mm}^{-1}$; $[\mathrm{X}]$ represents the individual 
$\mathrm{PM}_{2.5}$ species concentrations in $\mu \mathrm{g} \mathrm{m}^{-3} \cdot f(\mathrm{RH})$ is the humidification factor accounting for the impact of relative humidity on the growth of the hygroscopic aerosol.

The concentrations of ammonium sulfate and ammonium nitrate are calculated by multiplying $\left[\mathrm{SO}_{4}{ }^{2-}\right]$ and $\left[\mathrm{NO}_{3}{ }^{-}\right]$by factors of 1.38 and 1.29 , respectively, to account for paired ammonium ions. Organic matter is estimated from $1.6 \times$ [OC], this multiplier is suitable for urban aerosol (Turpin et al., 2001; Ye et al., 2017). The extinction effect of fine particulate matter on visibility impairment was studied, so we excluded the contributions of coarse particles and soil in $b_{\text {ext }}$ estimation since they only accounted for a small fraction of $\mathrm{PM}_{2.5}$ mass (Malm et al., 1994; Wang et al., 2003). So, the reconstructed equation used in this research is as follows:

$b_{\text {ext }} \approx 3 f(\mathrm{RH}) \times[$ ammonium sulfate $]+3 f(\mathrm{RH}) \times$ [ammonium nitrate $]+4 \times[$ Organic matter $]+10 \times[\mathrm{EC}]$

\section{RESULTS AND DISCUSSION}

\section{Meteorological Parameters and Aerosol Mass Concentration}

The new NAAQS of China set $\mathrm{PM}_{2.5}$ concentration limits for the 24-hour average of $75 \mu \mathrm{g} \mathrm{m}^{-3}$ for Grade II zones (MEP, 2012). The 24-hour average $\mathrm{PM}_{2.5}$ measured in this study in Nanjing ranged from $40.5 \mu \mathrm{g} \mathrm{m}^{-3}$ to $241.4 \mu \mathrm{g} \mathrm{m}^{-3}$ with an average of $104.0 \mu \mathrm{g} \mathrm{m}^{-3}$, severely exceeding the NAAQS of China and other standards recommended by the WHO $\left(25 \mu \mathrm{g} \mathrm{m}^{-3}\right)$ and the United States $\left(35 \mu \mathrm{g} \mathrm{m}^{-3}\right)$ (MEP, 2012; US EPA, 2013; WHO, 2006). According to the new NAAQS (Grade II), about $70 \%$ of days exceeded the standard during the measurement period. Fig. 2 displays the mass concentrations of $\mathrm{PM}_{1}, \mathrm{PM}_{1-2.5}$ and mass concentration ratios of $\mathrm{PM}_{1} / \mathrm{PM}_{2.5}$ in January 2015. The polluted period in this study is defined as the 24-hour average $\mathrm{PM}_{2.5}$ exceeds $75 \mu \mathrm{g} \mathrm{m}{ }^{-3}$. For example, the averaged
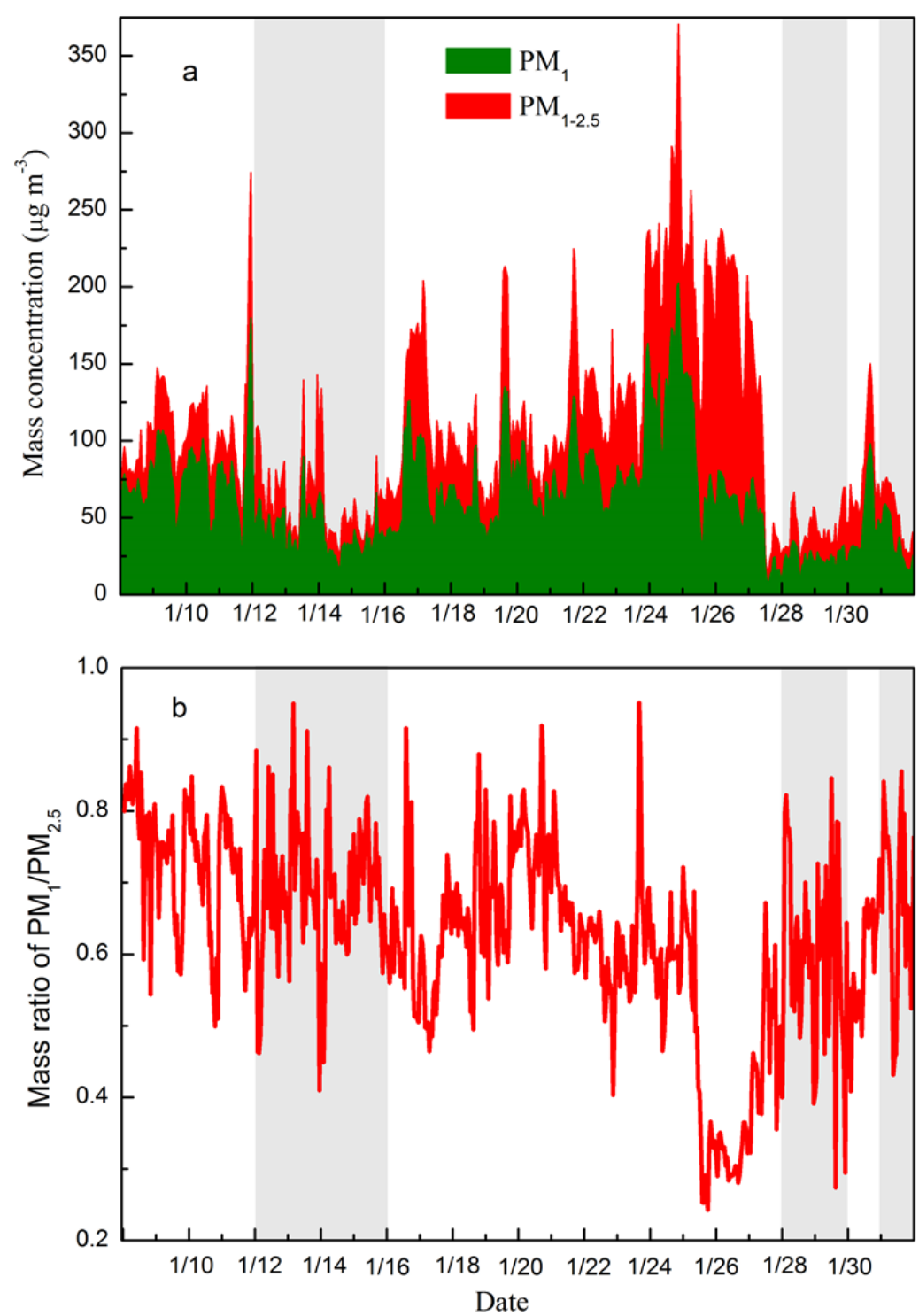

Fig. 2. Time series of (a) mass concentrations of $\mathrm{PM}_{1}$ and $\mathrm{PM}_{1-2.5}$; (b) mass ratios of $\mathrm{PM}_{1} / \mathrm{PM}_{2.5}$. The clean periods with low aerosol mass concentration are marked as gray shaded areas. 
$\mathrm{PM}_{2.5}$ mass concentration during the polluted periods reached $124.95 \pm 57.84 \mu \mathrm{g} \mathrm{m} \mathrm{m}^{-3}$, which was 2.3 times higher than that during the clean periods. The $\mathrm{PM}_{1}$ and $\mathrm{PM}_{2.5}$ hourly concentrations simultaneously reached peaks of 202.4 and $370.5 \mu \mathrm{g} \mathrm{m}^{-3}$, respectively, at 8:00 PM on 24 January. Then the mass concentrations decreased rapidly due to the occurrence of precipitation. The averaged mass ratios of $\mathrm{PM}_{1} / \mathrm{PM}_{2.5}$ during the polluted and clean periods were $0.62 \pm 0.14$ and $0.66 \pm 0.12$. The meteorological parameters during the measurement period are presented in Fig. 3. The averaged wind speed (WS) was $1.57 \mathrm{~m} \mathrm{~s}^{-1}$ and the wind was mainly northeasterly and northwesterly during this period. Average RH and visibility during the polluted periods were $63.31 \%$ and $4.1 \mathrm{~km}$; the lowest visibility of $0.94 \mathrm{~km}$ occurred in the evening of 25 January.

\section{Aerosol Optical Properties}

Aerosol optical parameters were obtained from 22 to 31 January which covered the polluted periods and clean periods before and after. Measurements of aerosol optical parameters on other days were not available because of instrument failure. Time series of hourly average aerosol optical parameters measured at dry RH are shown in Fig. 4: total scattering coefficients, backscattering ratio, asymmetry parameter at three wavelengths $(450,550$ and $700 \mathrm{~nm})$, absorption coefficient at $532 \mathrm{~nm}$, scattering Ångström exponent at 700-450 $\mathrm{nm}$ and mass scattering efficiencies. The scattering coefficient $\left(\sigma_{\mathrm{sp}}\right)$ decreased with increasing wavelength, while backscattering ratio increased with wavelength due to decreasing size parameters. They also showed an inverse variation trend, for example, high value of $\sigma_{\mathrm{sp}}$ occurred during 24-26 January corresponding with low $b_{\lambda}$. The averaged $\sigma_{\mathrm{sp}}$ at $550 \mathrm{~nm}$ during the polluted periods was $521 \pm 271 \mathrm{Mm}^{-1}$, which was almost 4.0 times higher than that observed during the clean periods. However, the average value for $b_{\lambda}$ during the polluted periods $(0.096$ \pm 0.008 at $550 \mathrm{~nm}$ ) was slightly lower than that of clean periods $(0.107 \pm 0.013)$, and those measured in Shijiazhang (0.175), Lanzhou (0.158), Shouxian (0.101) and a rural site of the Pearl River Delta (0.124), China (Zhang et al., 2004; Garland et al., 2008; Fan et al., 2010; Zhang et al., 2012). According to the calculation based on Mie theory, $b_{\lambda}$ will be larger than 0.10 if the particles' diameters are under about $1.5 \mu \mathrm{m}$ (Zhang et al., 2004). This result indicated that the content of fine particles with diameters less than $1.5 \mu \mathrm{m}$ was relatively high during the clean periods in Nanjing.

The scattering Ångström exponent $(\alpha)$ represents the wavelength dependence of scattering coefficient and is related to the slope of the number-size distribution or the mean size and relative concentrations of the accumulationand coarse-mode aerosol. The value of $\alpha$ varied from 0.31 to 1.67 , suggesting a mixture of fine- and coarse-mode particles during these pollution days. Compared to values during the clean periods, a lower value of $\alpha=0.99$ during the polluted periods indicated that the relatively large size particles were present, due to coagulation and hygroscopic growth at relatively high $\mathrm{RH}$ conditions. It is worth noting that the value of $\alpha$ was the lowest on 25 and 26 January, which is consistent with the pattern of $\mathrm{PM}_{1} / \mathrm{PM}_{2.5}$. The mean value of $\alpha$ during the polluted periods was smaller than 1.51 in a rural area near Guangzhou (Garland et al., 2008) and 1.1 measured in Beijing (Wang et al., 2015), but much higher than the 0.16 reported for dust storm days in Zhangye (Tian et al., 2010), which indicated a more dominant coarse-mode particle compared with the other locations. The MSE during the polluted periods in Nanjing varied from $1.40 \mathrm{~m}^{2} \mathrm{~g}^{-1}$ to $5.36 \mathrm{~m}^{2} \mathrm{~g}^{-1}$ with an average of $3.35 \mathrm{~m}^{2} \mathrm{~g}^{-1}$. The averaged value was much lower than that observed

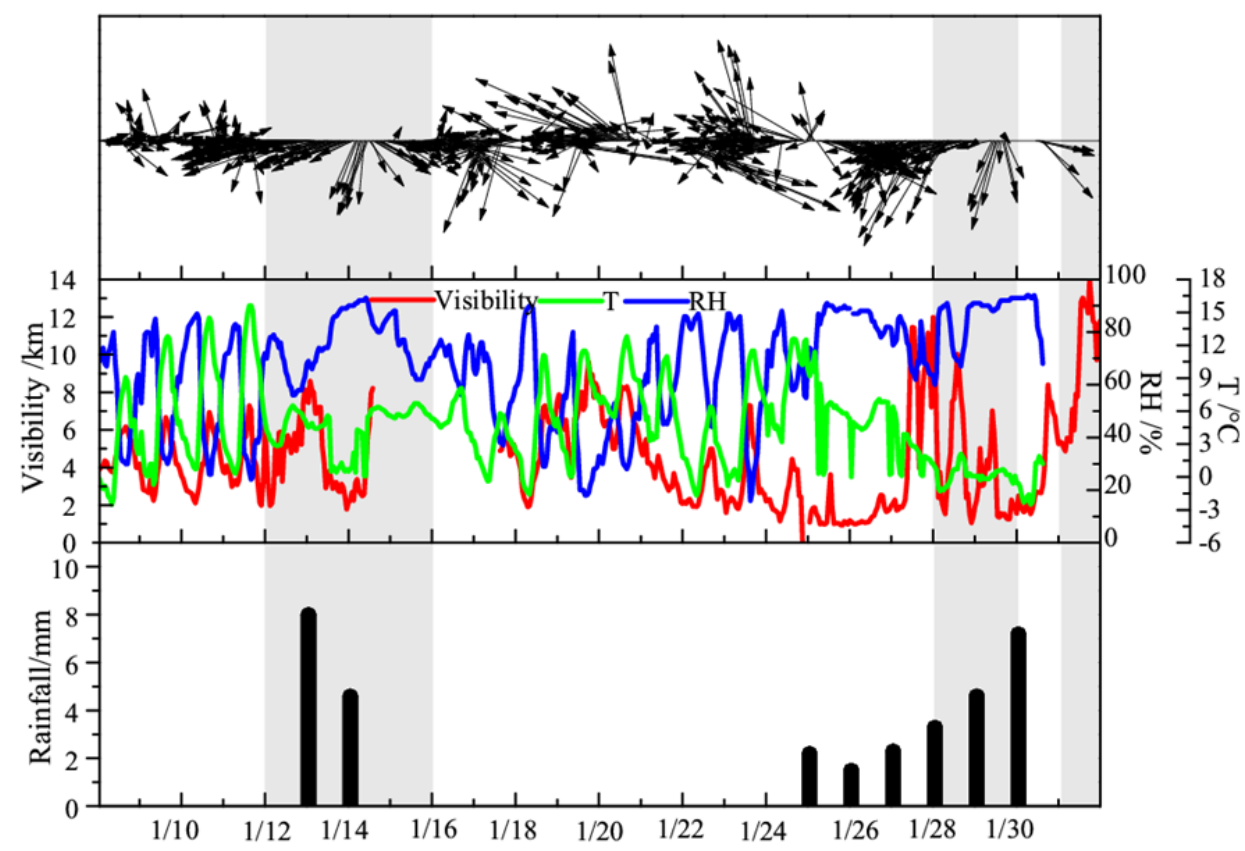

Fig. 3. Time series of meteorological factors: temperature, relative humidity, visibility, wind vector and rainfall during the measurement period. The clean periods are marked as gray shaded areas. 

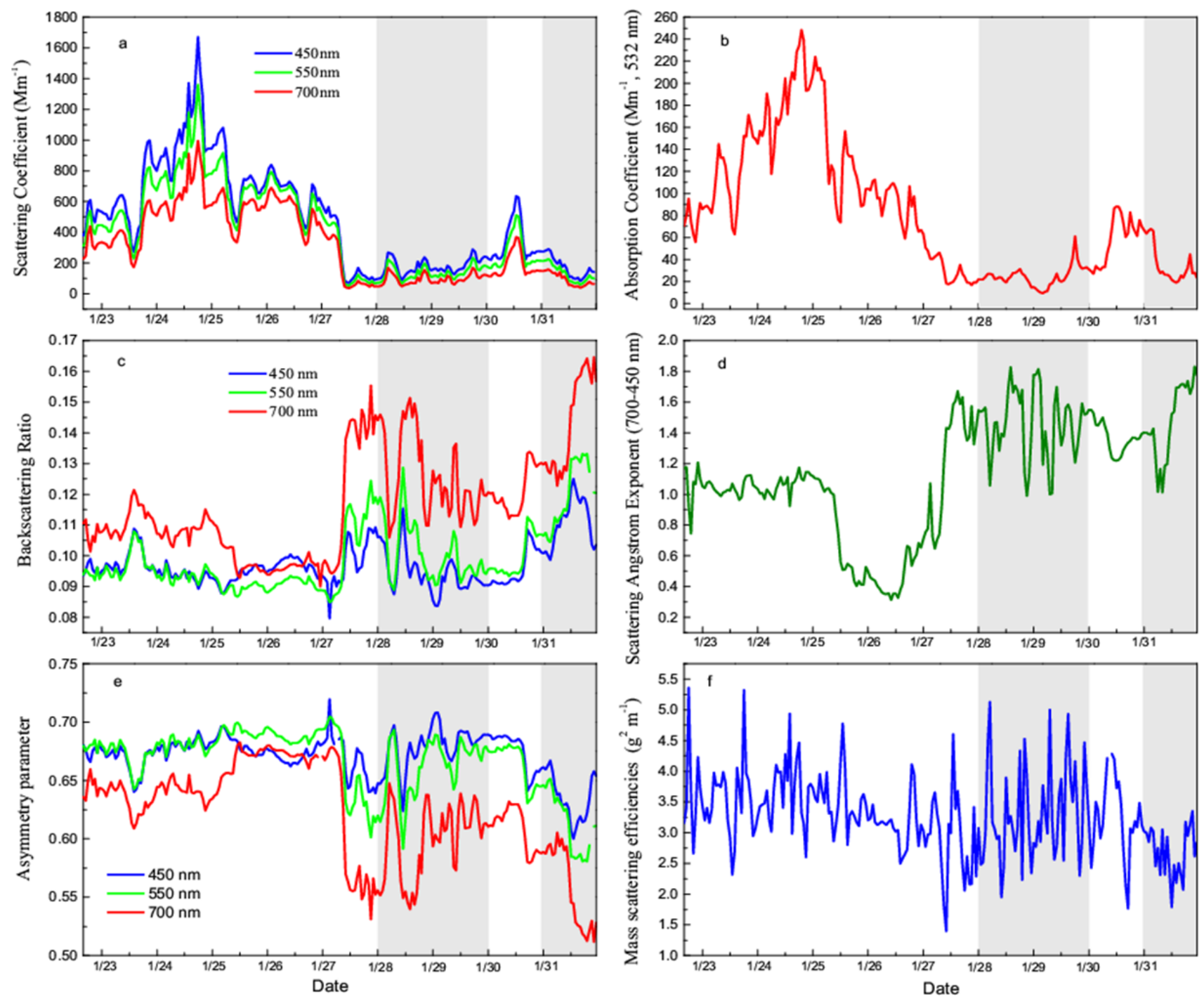

Fig. 4. Time series of (a) scattering coefficients, (b) absorption coefficients, (c) backscattering ratios, (d) scattering Ångström exponent (450-700 nm), (e) asymmetry parameter at wavelengths of $450 \mathrm{~nm}, 550 \mathrm{~nm}$ and $700 \mathrm{~nm}$, and (f) mass scattering efficiencies. The clean periods are marked as gray areas.

during June 2008-May 2009 at Beijing with a value of $5.88 \mathrm{~m}^{2} \mathrm{~g}^{-1}$, but larger than that observed in Taiwan with a range of $0.7-1.6 \mathrm{~m}^{2} \mathrm{~g}^{-1}$ and the clean periods in Nanjing with an average of $3.10 \mathrm{~m}^{2} \mathrm{~g}^{-1}$ (Chang et al., 2006; Zhao et al., 2011).

The absorption coefficients $\left(\sigma_{\text {ap }}\right)$ showed a similar variation trend with scattering coefficients. The maximum daily average $\sigma_{\text {sp }}$ and $\sigma_{\text {ap }}$ at $532 \mathrm{~nm}$ occurred on 24 January with value of $1076 \pm 246 \mathrm{Mm}^{-1}$ and $185 \pm 33 \mathrm{Mm}^{-1}$ respectively. The low WS and high $\mathrm{RH}$ on these days encouraged the hygroscopic growth and accumulation of aerosol particles. The averaged $\sigma_{\mathrm{ap}}$ during the polluted periods $\left(102 \pm 58 \mathrm{Mm}^{-1}\right)$ was about 3.5 times higher than those during the clean periods, indicating less absorbing aerosols in Nanjing. The value during the polluted periods in Nanjing was much greater than that observed in Lhasa (Zhu et al., 2017), but it was comparable with the result of agricultural field burning event in Shouxian (Fan et al., 2010). The average values of $g_{\lambda}$ during the polluted periods at 450,550 and $700 \mathrm{~nm}$ were $0.67 \pm 0.01,0.68 \pm 0.02$ and $0.64 \pm 0.03$ respectively, which were slightly higher than those during the clean periods and observed during an intense haze episode in winter of Beijing (Wang et al., 2015). High value of $g_{\lambda}$ was possibly attributed to the higher contribution of large size particles, and indicated the particles were predominant in forward scattering.

\section{Aerosol Chemical Properties}

Time series of aerosol absorption coefficients at $370 \mathrm{~nm}$, $880 \mathrm{~nm}$ and $\mathrm{BC}_{\mathrm{ff}}$ and $\mathrm{BC}_{\mathrm{bb}}$ concentrations with 1-h time resolution are displayed in Fig. 5. Higher absorption coefficients were observed at $370 \mathrm{~nm}$, with an average value of $89 \mathrm{Mm}^{-1}$, while the mean coefficient at $880 \mathrm{~nm}$ was about $26 \mathrm{Mm}^{-1}$ for the duration. This is because a considerable number of light absorbing organic carbon or brown-carbon significantly absorb light towards shorter wavelengths. The mean concentration of $\mathrm{BC}_{\mathrm{ff}}$ and $\mathrm{BC}_{\mathrm{bb}}$ were $1.94 \mu \mathrm{g} \mathrm{m}^{-3}$ and $0.57 \mu \mathrm{g} \mathrm{m}^{-3}$ respectively during the whole period, indicated 


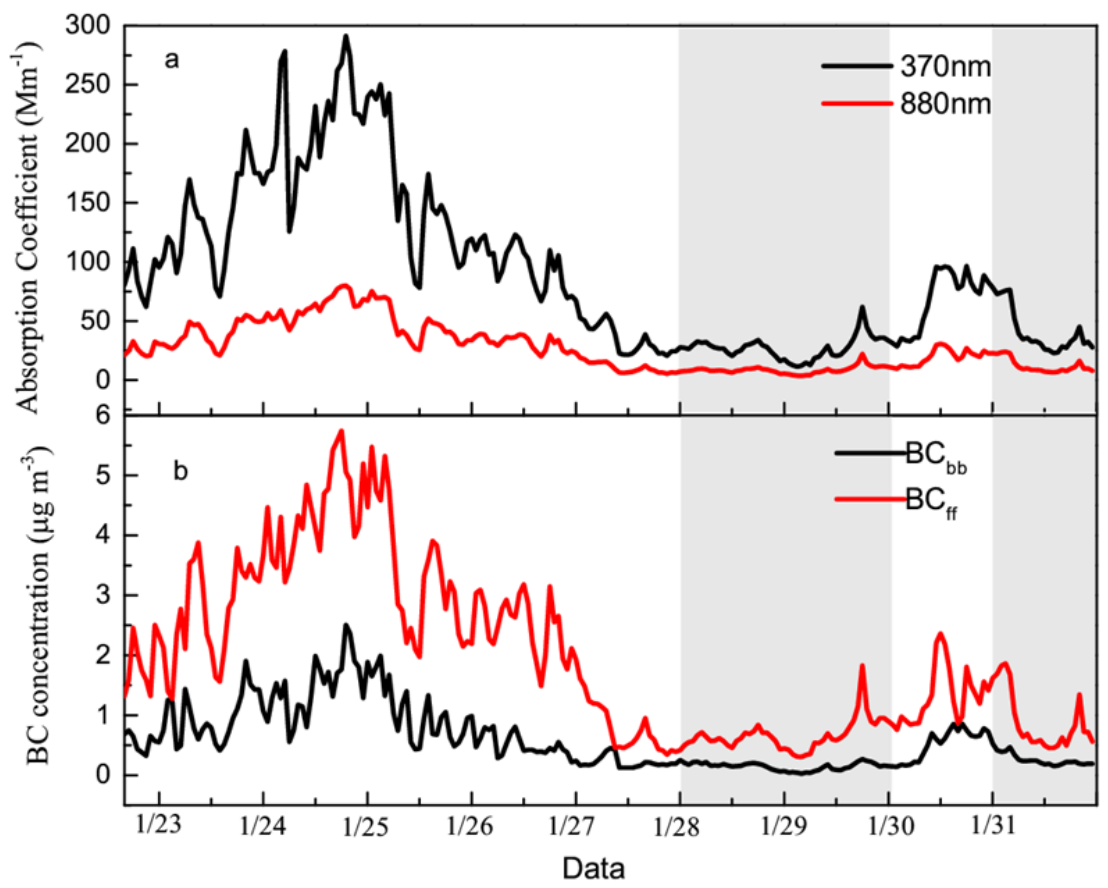

Fig. 5. Time series of hourly mean absorption coefficient and the concentrations of $\mathrm{BC}_{\mathrm{ff}}$ and $\mathrm{BC}_{\mathrm{bb}}$.

that the fuel fossil burning was main emission source of $\mathrm{BC}$ in the north of Nanjing. The highest concentrations of $\mathrm{BC}_{\mathrm{ff}}$ and $\mathrm{BC}_{\mathrm{bb}}$ occurred from 24 to 25 January during the polluted episode with average values about $3.89 \mu \mathrm{g} \mathrm{m}^{-3}$ and $1.25 \mu \mathrm{g} \mathrm{m}^{-3}$ respectively, accounting for $75.5 \%$ and $24.5 \%$ of the total $\mathrm{BC}$ concentration respectively. The contribution of biomass burning to $\mathrm{BC}$ were slightly higher during the polluted days, suggested that biomass burning emission also has certain contribution to the heavy pollution formation.

Temporal variations of concentrations of WSIs and carbonaceous compounds in $\mathrm{PM}_{2.5}$ in January 2015 are presented in Fig. 6. The 6-hour sum of WSIs concentrations ranged from 15.4 to $217.8 \mu \mathrm{g} \mathrm{m}^{-3}$ with a monthly mean of $71.0 \mu \mathrm{g} \mathrm{m}^{-3}$, accounting for $49.5 \pm 20.7 \%$ of the total $\mathrm{PM}_{2.5}$ mass concentration (filter sampling). The highest 6hour concentration of WSIs occurred on 24 January and reached $181.6 \mu \mathrm{g} \mathrm{m}^{-3}$. In general, $\mathrm{NO}_{3}{ }^{-}, \mathrm{SO}_{4}{ }^{2-}$ and $\mathrm{NH}_{4}{ }^{+}$ were the dominant WSIs and accounted for $85.7 \%$ of the total mass concentrations of measured ions. Tian et al. (2015) also reported that the secondary ions $\left(\mathrm{NO}_{3}{ }^{-}, \mathrm{SO}_{4}{ }^{2-}\right.$ and $\mathrm{NH}_{4}^{+}$) dominated in $\mathrm{PM}_{2.5}$ and accounted for $86 \%$ of the total mass of water-soluble ions. The water-soluble ion average mass concentrations ranked in the order of $\mathrm{NO}_{3}{ }^{-}>$ $\mathrm{SO}_{4}{ }^{2-}>\mathrm{NH}_{4}^{+}>\mathrm{Cl}^{-}>\mathrm{K}^{+}>\mathrm{NO}_{2}{ }^{-}>\mathrm{Ca}^{2+}>\mathrm{Na}^{+}>\mathrm{F}^{-}>$ $\mathrm{Mg}^{2+}$. This order was consistent with that observed during the polluted periods, but it changed slightly during the clean periods. On average, the $\mathrm{NO}_{3}^{-}$was the most abundant ion in January 2015 in Nanjing with a monthly mean concentration of $26.2 \pm 18.6 \mu \mathrm{g} \mathrm{m}^{-3}$, accounting for $35.8 \pm$ $24.6 \%$ of the total measured WSIs. Ions of $\mathrm{SO}_{4}{ }^{2-}$ and $\mathrm{NH}_{4}{ }^{+}$ were the other two major species, accounting for $28.6 \pm$ $17.2 \%$ and $22.5 \pm 13.5 \%$ of the total WSIs respectively. Wei et al. (2017) also reported that the higher percentage of secondary species to $\mathrm{PM}_{2.5}$ occurred in Nanjing, and indicated that the aerosol was mainly caused by the secondary transformation of local air pollutants. The high concentration of secondary inorganic species implied the need of further control measures for their precursor gases, $\mathrm{SO}_{2}, \mathrm{NO}_{\mathrm{x}}$ and $\mathrm{NH}_{3}$, emitted from fossil fuel combustion, industrial emissions and agriculture sources over the local and surrounding area of Nanjing. The monthly concentration of $\mathrm{Cl}^{-}, \mathrm{K}^{+}, \mathrm{NO}_{2}^{-}, \mathrm{Ca}^{2+}, \mathrm{Na}^{+}, \mathrm{F}^{-}$and $\mathrm{Mg}^{2+}$ ranged from 0.1 to $5.9 \mu \mathrm{g} \mathrm{m}^{-3}$, accounting for $13 \%$ of the total ion concentration.

The 6-hour concentration of OC during the study period ranged from 4.4 to $63.2 \mu \mathrm{g} \mathrm{m}^{-3}$ with a monthly mean of $21.0 \mu \mathrm{g} \mathrm{m}^{-3}$, while the concentration of EC varied between $0.7 \mu \mathrm{g} \mathrm{m}^{-3}$ and $14.3 \mu \mathrm{g} \mathrm{m}^{-3}$ with a monthly mean of $5.7 \mu \mathrm{g} \mathrm{m}^{-3}$. The monthly mean of OC and EC in winter of Nanjing was higher than that observed in summer of Beijing (Tian et al., 2015), but lower than that measured in summer of Xi' an (Cao et al., 2007). An average concentration of OC achieved $44 \mu \mathrm{g} \mathrm{m} \mathrm{m}^{-3}$ during November 1999 in Linan, and OC accounted for $\sim 50 \%$ of the $\mathrm{PM}_{2.5}$ mass during the field study ( $\mathrm{Xu}$ et al., 2002).

Table 1 summarizes aerosol physical and chemical characteristics during the study period. The lower concentration of aerosol chemical species during the clean period was mainly due to precipitation. The averaged mass concentrations of $\mathrm{OC}$ and $\mathrm{EC}$ in $\mathrm{PM}_{2.5}$ during the polluted periods reached $24.7 \pm 9.8 \mu \mathrm{g} \mathrm{m}^{-3}$ and $6.8 \pm 2.9 \mu \mathrm{g} \mathrm{m}^{-3}$. These values were 2.3 and 2.7 times higher than those during the clean periods (i.e., $10.7 \pm 3.6$ and $2.5 \pm 0.9 \mu \mathrm{g} \mathrm{m}^{-3}$ for $\mathrm{OC}$ and EC, respectively). Higher concentrations during the polluted periods are expected due to emissions from fossil fuel and biomass burning, secondary formation from gasto-particle conversion processes and stable meteorological conditions. The measured ion and carbonaceous species 

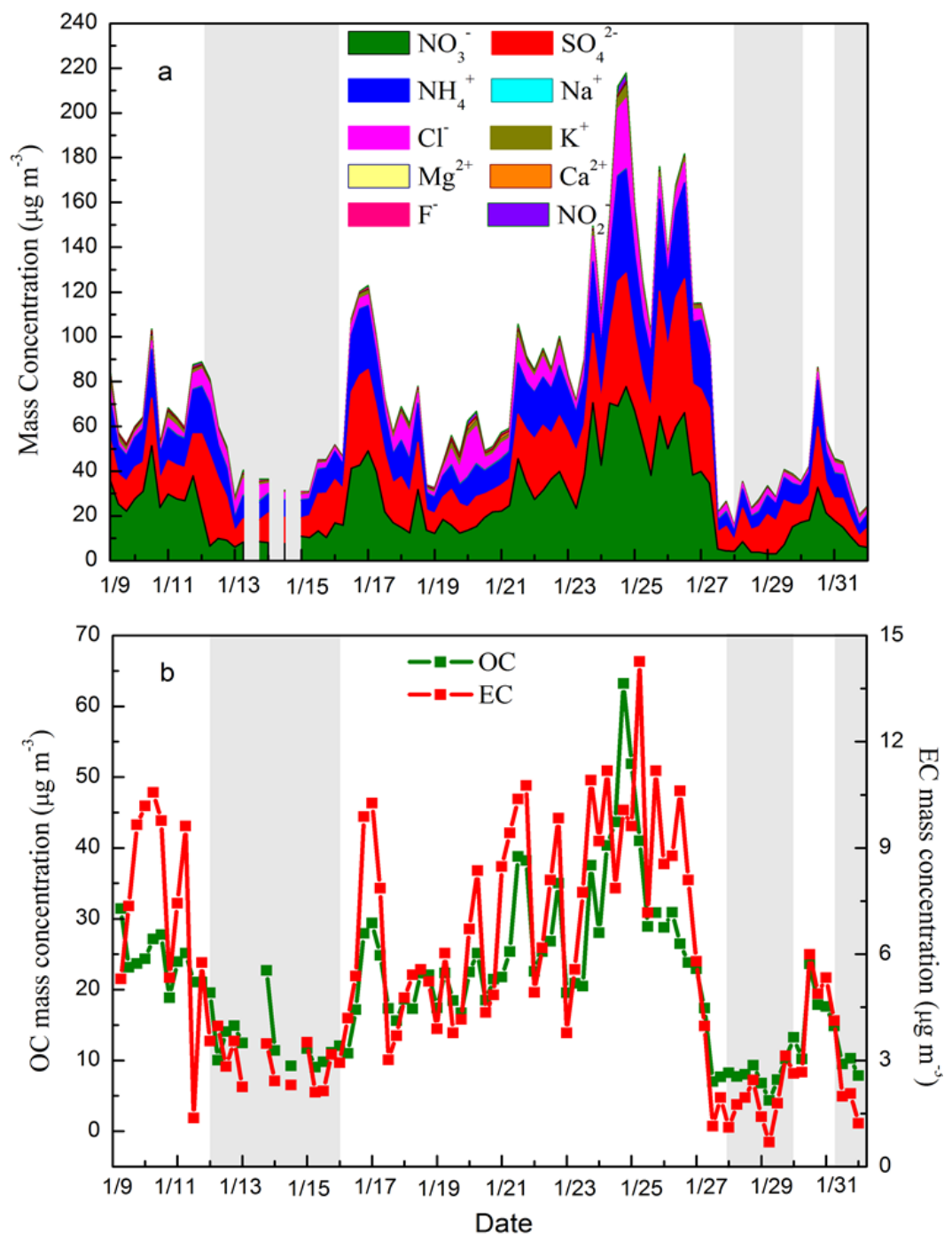

Fig. 6. Temporal variations of (a) water-soluble ions and (b) organic carbon and elemental carbon in $\mathrm{PM}_{2.5}$ in January 2015. The clean periods with low mass concentration of water-soluble ions and carbonaceous aerosols are marked as gray shaded areas.

accounted for $52 \%$ and $19 \%$ of the total $\mathrm{PM}_{2.5}$ for the polluted periods, and those of $36 \%$ and $13 \%$ for the clean periods, respectively.

The average mass concentrations of $\mathrm{NO}_{3}{ }^{-}, \mathrm{SO}_{4}{ }^{2-}$ and $\mathrm{NH}_{4}{ }^{+}$during the polluted periods increased approximately 2-3 times compared to the clean periods, which might result from the accelerated formation of secondary aerosols under the humid conditions that existed during the polluted period. The $\mathrm{NO}_{3}{ }^{-} / \mathrm{SO}_{4}{ }^{2-}$ average ratios were 0.64 and 1.39 during the clean and polluted periods, respectively. The higher ratio during the polluted periods indicated the important role that $\mathrm{NO}_{\mathrm{x}}$ and $\mathrm{NH}_{3}$ emissions play in contributing to severe haze episodes during stagnation periods. Low temperature and high humidity in winter favor a shift from the gas phase as nitric acid $\left(\mathrm{HNO}_{3}\right)$ and $\mathrm{NH}_{3}$ to the particle phase as ammonium nitrate $\left(\mathrm{NH}_{4} \mathrm{NO}_{3}\right)$ (US EPA, 1999). Ca, which can be regarded as a tracer for soil source, was 3.4 times higher during the polluted periods than during the clean periods. This suggests that dust emitted from roads and construction sites had a significant contribution to the pollution episode, even for $\mathrm{PM}_{2.5}$.

It is interesting to note that the concentration of $\mathrm{PM}_{2.5}$ remained high from 24 to 27 January and the daily mean value ranging between $76 \mu \mathrm{g} \mathrm{m}^{-3}$ and $241 \mu \mathrm{g} \mathrm{m} \mathrm{m}^{-3}$. Nevertheless, the ratio of $\mathrm{PM}_{1} / \mathrm{PM}_{2.5}$ decreased sharply started from 25 January, and a lower mass ratio of $\mathrm{PM}_{1} / \mathrm{PM}_{2.5}$ occurred from noon of 25 January to midnight 26 January with an average of 0.31 (see Fig. 2(b)). Compared with aerosol chemical and optical properties on 24 January, the concentrations of WSIs, scattering and absorption coefficients were all decreased on 25 January. The time discrepancies in aerosol chemical compositions and the $\mathrm{PM}_{1} / \mathrm{PM}_{2.5}$ ratio can be explained by the transformation of meteorological conditions. The wind direction was north to northeast on 24 January but veered to northwest and became stronger on 25 January. Besides, there were several rainfalls started from 25 January. 


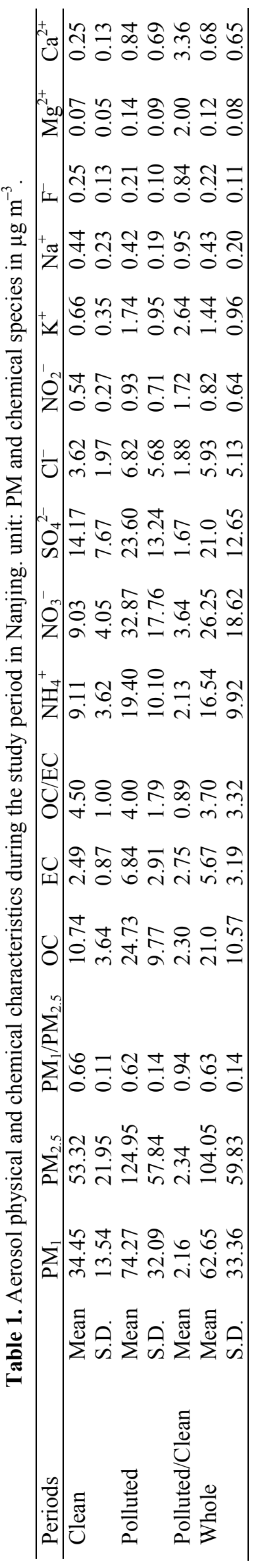

Contributions of Chemical Species to Light Extinction

Formula (11) assumes that $\mathrm{SO}_{4}{ }^{2-}$ and $\mathrm{NO}_{3}{ }^{-}$were completely neutralized by $\mathrm{NH}_{4}^{+}$. Examination of a scatterplot of $\left[\mathrm{NH}_{4}{ }^{+}\right]$versus $\left(\left[\mathrm{NO}_{3}{ }^{-}\right]+2\left[\mathrm{SO}_{4}{ }^{2-}\right]\right)$ (in moles) indicated that this assumption is reasonable for the study site; measured $\mathrm{NH}_{4}^{+}$was sufficient to neutralize $\mathrm{NO}_{3}^{-}$and $\mathrm{SO}_{4}{ }^{2-}$ during the observation period in Nanjing (Fig. 7).

Both calculated and estimated aerosol extinction coefficients are shown in Fig. 8(a) and their relationship is linearly fitted in Fig. 8(b). The hygroscopic growth of aerosol was estimated according to different values of $f(\mathrm{RH})$, which were selected from Malm and Day (2001) and Yan et al. (2009). The average estimated chemical $b_{\text {ext }}$ based on the values of $f(\mathrm{RH})_{\text {Malm }}$ were $920 \mathrm{Mm}^{-1}$ during 22-27 January (dense pollution episodes). However, this value decreased to $708 \mathrm{Mm}^{-1}$ when values of $f(\mathrm{RH})$ were selected from studies conducted at a Chinese urban site in Beijing $\left(f(\mathrm{RH})_{\text {Yan }}\right)$ (Yan et al., 2009). As shown in Fig. 8(b), the estimated chemical $b_{\text {ext }}$ correlated strongly with the calculated $b_{\text {ext }}$. Nevertheless, at high $b_{\text {ext }}$ range (such as polluted periods), the discrepancies between calculated $b_{\text {ext }}$ and estimated chemical $b_{\text {ext }}$ became larger (see Fig. 8(a)), sometimes exceeding and sometimes falling below calculated values. The discrepancies could be associated with uncertainties in $f(\mathrm{RH})$. It is interesting to see the light extinction was largely overestimated using $\mathrm{f}(\mathrm{RH})_{\text {Malm }}$ on the days of 25 January 2015 and 26 January 2015, which was related with decreased sratio of $\mathrm{PM}_{1.0} / \mathrm{PM}_{2.5}$. The particulates grew to large size and mass scattering efficiencies for sulfate and nitrate in IMPROVE formula was no longer suitable to estimate light extinction. The estimated $b_{\text {ext }}$ based on $f(\mathrm{RH})_{\text {Yan }}$ significantly correlated with the calculated values than those based on $f(\mathrm{RH})_{\text {Malm }}$ with a regression slope of 0.75 and $r=0.90$. This is attributed to more similar pollution aerosol types in Nanjing and Beijing vs. the Malm et al. $f(\mathrm{RH})$ values which are derived from measurements in the United States. Differences between calculated extinction and reconstructed values

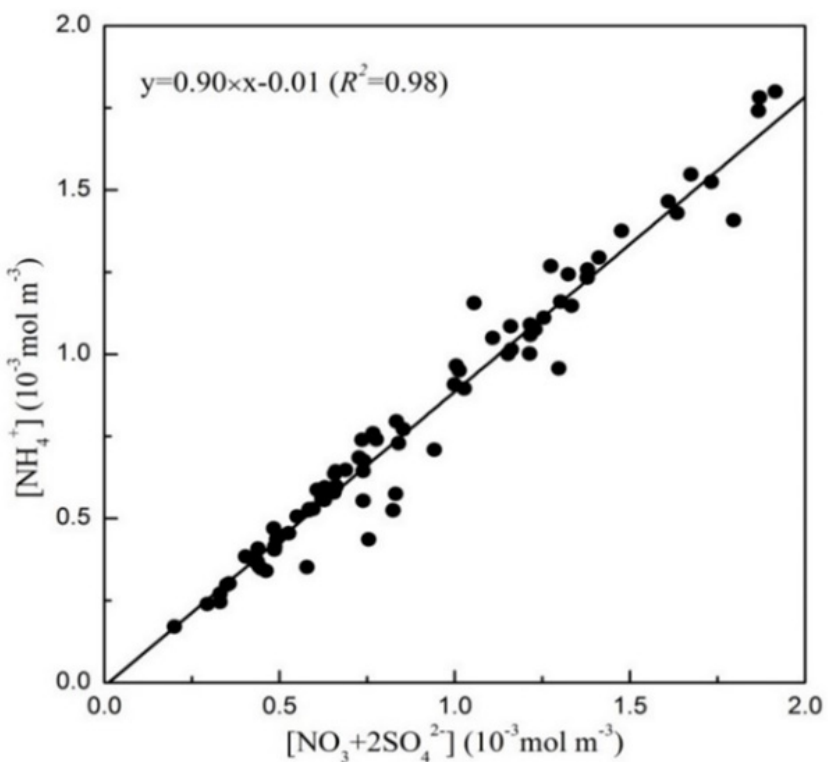

Fig. 7. Scatter plot of $\left[\mathrm{NH}_{4}{ }^{+}\right]$versus $\left[\mathrm{NO}_{3}{ }^{-}\right]+2 \times\left[\mathrm{SO}_{4}{ }^{2-}\right]$. 

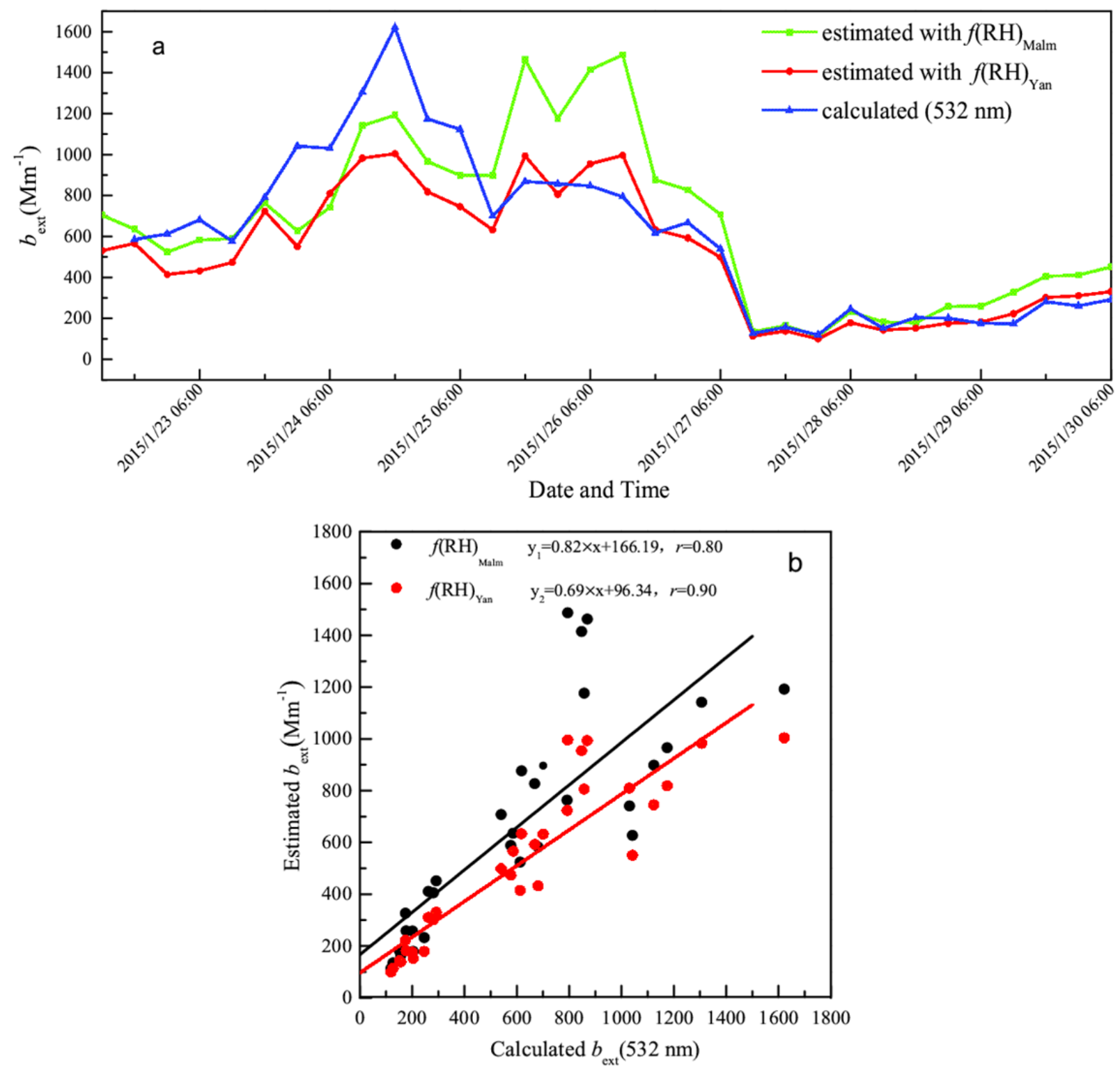

Fig. 8. (a) Temporal distribution of aerosol extinction coefficients according to the estimation of revised IMPROVE equation $(f(\mathrm{RH})$ are from Malm and Day (2010) and Yan et al. (2009)) and calculation by instruments. (b) Comparison between the calculated and estimated extinction coefficients.

derived from the IMPROVE equation might also be expected if aerosol size distributions differ between Nanjing and U.S. aerosols upon which the IMPROVE formula is based.

Based on the estimation of $f(\mathrm{RH})_{\text {Yan }}$, an average reconstructed $b_{\text {ext }}$ was $370 \mathrm{Mm}^{-1}$ during the total measurement period. This value was greater than that measured in Guangzhou (346 $\mathrm{Mm}^{-1}$ ) (Zhang et al., 2010), but lower than has been observed in Beijing $\left(504 \mathrm{Mm}^{-1}\right)$ (Huang et al., 2015), Chengdu (900 $\mathrm{Mm}^{-1}$ ) (Wang et al., 2013), Xi'an (912 $\mathrm{Mm}^{-1}$ ) (Cao et al., 2012) and Delhi $\left(644 \mathrm{Mm}^{-1}\right)$ (Singh et al., 2008). The total average light extinction contributions of aerosol components during polluted and clean periods in Nanjing are presented in Fig. 9. The apportionment contributions from $\mathrm{NH}_{4} \mathrm{NO}_{3}$, $\mathrm{OM},\left(\mathrm{NH}_{4}\right)_{2} \mathrm{SO}_{4}$ and $\mathrm{EC}$ during polluted periods were $30.8 \%, 31.5 \%, 23.9 \%$ and $13.8 \%$ respectively, indicating the dominant contributions of nitrate and organic matter to light extinction during winter polluted periods in Nanjing. Organic matter was the largest contributor to visibility degradation during the polluted periods, while sulfate, which is expected to have more regional source contributions, was the largest contributor for clean periods.

\section{CONCLUSIONS}

Based on in situ measurements, the physical, chemical, and optical properties of aerosols were determined in January 2015 at an urban-industrial site in Nanjing, China. The polluted periods showed a significant decrease in visibility and an increase in particle mass loading. The average mass concentrations of $\mathrm{PM}_{1}$ and $\mathrm{PM}_{2.5}$ during the polluted periods were $74.3 \pm 32.1 \mu^{-3} \mathrm{~m}^{-3}$ and $125.0 \pm$ 

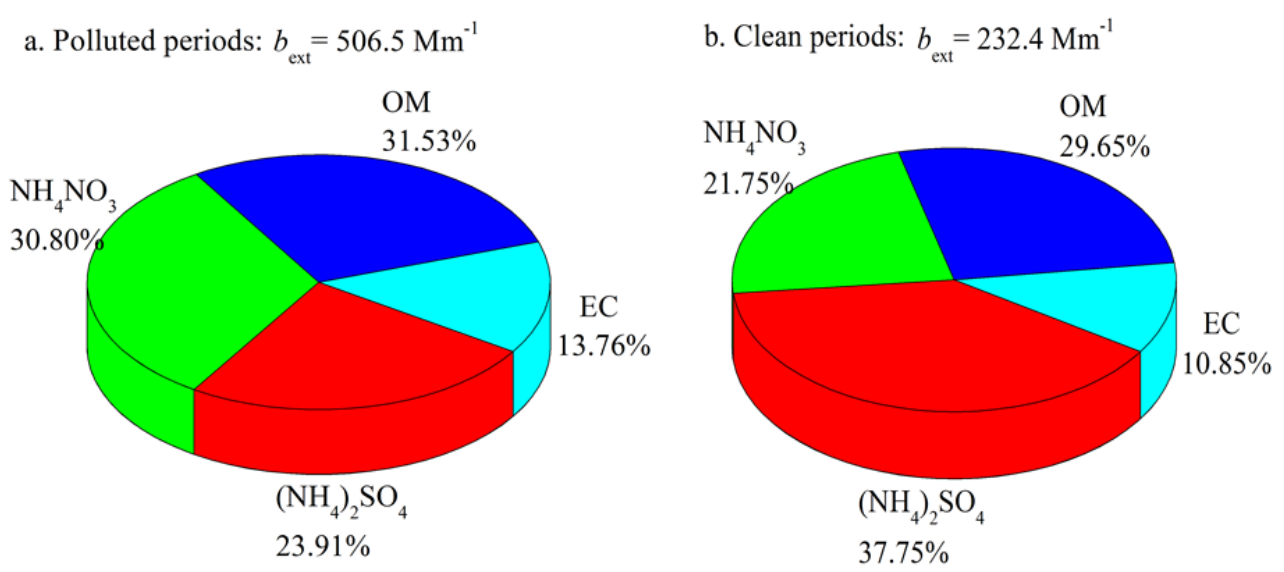

Fig. 9. Relative contributions of aerosol chemical components to light extinction coefficient during (a) polluted periods and (b) clean periods in January 2015 in Nanjing.

$57.8 \mu \mathrm{g} \mathrm{m}^{-3}$, respectively. The average scattering and absorption coefficients at $532 \mathrm{~nm}$ during the polluted periods were $620 \pm 320 \mathrm{Mm}^{-1}$ and $102 \pm 58 \mathrm{Mm}^{-1}$ - about 3.5 times higher than those during the clean periods. Higher values of the asymmetry factor and lower values of the backscattering ratio and scattering Ångström exponent indicated an increasing fraction of relatively large size particles during the polluted periods, which may reflect local dust generation, aerosol hygroscopic growth during the high humidity air stagnation periods, and/or coagulation and condensational growth of aerosols under extremely polluted conditions.

The average mass concentration of the dominant watersoluble ions $\left(\mathrm{SO}_{4}{ }^{2-}, \mathrm{NO}_{3}{ }^{-}\right.$and $\left.\mathrm{NH}_{4}{ }^{+}\right)$in $\mathrm{PM}_{2.5}$ was about $2-$ 3 times higher during the polluted periods than during the clean periods following precipitation. Similar to the ions, the average mass concentrations of $\mathrm{OC}$ and $\mathrm{EC}$ in $\mathrm{PM}_{2.5}$ during the polluted periods were 2.3 and 2.7 times higher than those during clean periods. The average $\mathrm{OC} / \mathrm{EC}$ ratio during the polluted period was 3.6, consistent with a mix likely of primary emissions and secondary organic aerosol formation.

The estimated average chemical extinction coefficient based on the revised IMPROVE equation was $506.5 \mathrm{Mm}^{-1}$ during the polluted periods - much greater than that observed in many areas of the world. Light extinction apportionment showed that ammonium nitrate, organic matter, ammonium sulfate, and elemental carbon contributed fractions of $30.8 \%$, $31.5 \%, 23.9 \%$, and $13.8 \%$ respectively. The dominant contribution of organic matter and nitrate to extinction during haze episodes, in contrast to sulfate being the largest contributor during cleaner periods, points to the importance of local sources of organic components, $\mathrm{NO}_{\mathrm{x}}$, and $\mathrm{NH}_{3}$ to fine particle formation in winter stagnation episodes.

\section{ACKNOWLEDGMENTS}

This work was supported by the National Key Research and Development Program of China (2016YFC0203500, Task \#1), the National Natural Science Foundation of China (Grant Nos. 91544229, 41475142 and 41575132), the Natural Science Foundation of Jiangsu Province of China (BK20170943), the Opening Project of Shanghai Key Laboratory of Atmospheric Particle Pollution and Prevention (LAP ${ }^{3}$ ) (Grant No. FDLAP16004), Natural Science Foundation of Guangdong Province of ChinaMajor Basic Research and Cultivation Projects (2015A030308014), Qing Lan Project and the Priority Academic Program Development (PAPD) of Jiangsu Higher Education Institutions. We acknowledge work team of the China Meteorological Administration (CMA) meteorology observational field for maintenance in meteorological observation instrument.

\section{REFERENCES}

An, J.L., Wang, H.L., Shen, L.J., Zhu, B., Zou, J.N., Gao, J.H. and Kang, H.Q. (2015). Characteristics of new particle formation events in Nanjing, China: Effect of water-soluble ions. Atmos. Environ. 108: 32-40.

Anderson, T.L. and Ogren, A.J. (1998). Determining aerosol radiative properties using the TSI3563 integrating nephelometer. Aerosol Sci. Technol. 29: 57-69.

Andrews, E., Sheridan, P.J., Fiebig, M., McComiskey, M., Ogren, J.A., Arnott, P., Covert, D., Elleman, R., Gasparini, R., Collins, D., Jonsson, H., Schmid, B. and Wang, J. (2006). Comparison of methods for deriving aerosol asymmetry parameter. J. Geophys. Res. 111: D05S04.

Cao, J.J., Wang, Q.Y., Chow, J.C., Watson, J.G., Tie, X.X., Shen, Z.X., Wang, P. and An, Z.S. (2012). Impacts of aerosol compositions on visibility impairment in Xi'an, China. Atmos. Environ. 59: 559-566.

Chang, S.Y., Fang, G.C., Chou, C. and Chen, W.N. (2006). Chemical compositions and radiative properties of dust and anthropogenic air masses study in Taipei Basin, Taiwan, during spring of 2004. Atmos. Environ. 40: 7796-7809.

Che, H., Zhang, X., Li, Y., Zhou, Z. and Qu, J.J. (2007). Horizontal visibility trends in China 1981-2005. Geophys. Res. Lett. 34: L24706.

Coen, C.M., Weingartner, E., Apituley, A., Ceburnis, D., Fierz-Schmidhauser, R., Flentje, H., Henzing, J.S., 
Jennings, S.G., Moerman, M., Petzold, A., Schmid, O. and Baltensperger, U. (2010). Minimizing light absorption measurement artifacts of the Aethalometer: Evaluation of five correction algorithms. Atmos. Meas. Tech. 3: 457-474.

Dong, Y.Q., Yin, Y., Qian, L. and An, J.L. (2007). Analysis of the characteristics of hazy phenomena in Nanjing area. China Environ. Sci. 27: 584-588. (in Chinese)

Drinovec, L., Močnik, G., Zotter, P., Prévôt, A.S.H., Ruckstuhl, C., Coz, E., Rupakheti, M., Sciare, J., Müller, T., Wiedensohler, A. and Hansen, A.D.A. (2015). The "dual-spot" aethalometer: An improved measurement of aerosol black carbon with real-time loading compensation. Atmos. Meas. Tech. 7: 10179-10220.

Du, W., Zhang, Y., Chen, Y., Xu, L., Chen, J., Deng, J., Hong, Y. and Xiao, H. (2017). Chemical characterization and source apportionment of $\mathrm{PM}_{2.5}$ during spring and winter in the Yangtze River Delta, China. Aerosol Air Qual. Res. 17: 2165-2180.

Duan, F.K., He, K.B., Ma, Y.L., Yang, F.M., Yu, X.C., Cadle, S.H., Chan, T. and Mulawa, P.A. (2006). Concentration and chemical characteristics of $\mathrm{PM}_{2.5}$ in Beijing, China: 2001-2002. Sci. Total Environ. 355: 264275.

Esteve, A.R., Estelles, V., Utrillas, M.P. and MartinezLazano, J.A. (2012). In-situ integrating nephelometer measurements of the scattering properties of atmospheric aerosols at an urban coastal site in western Mediterranean. Atmos. Environ. 47: 43-50.

Fan, X., Chen, H., Xia, X., Li, Z. and Cribb, M. (2010). Aerosol optical properties from the atmospheric radiation measurement mobile facility at Shouxian, China. $J$. Geophys. Res. 115: 9-12.

Gao, L., Jia, G., Zhang, R., Che, H., Fu, C., Wang, T., Zhang, M., Jiang, H. and Yan, P. (2011). Visual range trends in the Yangtze River delta region of China, 19812005. J. Air Waste Manage. Assoc. 61: 843-849.

Garland, R.M., Yang, H., Schmid, O., Rose, D., Nowak, A., Achtert, P., Wiedensohler, A., Takegawa, N., Kita, K., Miyazaki, Y., Kondo, Y., Hu, M., Shao, M., Zeng, L.M., Zhang, Y.H., Andreae, M.O. and Pöschl, U. (2008). Aerosol optical properties in a rural environment near the mega-city Guangzhou, China: Implications for regional air pollution, radiative forcing and remote sensing. Atmos. Chem. Phys. 8: 5161-5186.

Herich, H., Hueglin, C. and Buchmann, B.A (2011). 2.5 year's source apportionment study of black carbon from wood burning and fossil fuel combustion at urban and rural sites in Switzerland. Atmos. Meas. Tech. 4: 14091420 .

Huang, Y.H., Li, M., Qu, S., Yan, J., Sun, X.S. and Pan, T. (2015). Characteristics of different components of PM and contribution to ambient light extinction coefficient in Beijing. Res. Environ. Sci. 28: 1193-1199. (in Chinese).

Jung, J., Lee, H., Kim, Y.J., Liu, X., Zhang, Y., Hu, M. and Sugimoto, N. (2010). Optical properties of atmospheric aerosols obtained by in situ and remote measurements during 2006 Campaign of Air Quality Research in Beijing (CAREBeijing-2006). J. Geophys. Res. 114: 1065-1066.
Jing, J., Wu, Y., Tao, J., Che, H., Xia, X., Zhang, X., Yan, P., Zhao, D. and Zhang, L. (2015). Observation and analysis of near-surface atmospheric aerosol optical properties in urban Beijing. Particuology 18: 144-154.

Kirchstetter, T.W., Novakov, T. and Hobbs, P.V. (2004). Evidence that the spectral dependence of light absorption by aerosols is affected by organic carbon. $J$. Geophys. Res. 109: 21208.

Kong, S.F., Li, L., Li, X.X., Yin, Y., Chen, K., Liu, D.T., Yuan, L., Zhang, Y.J., Shan, Y.P. and Ji, Y.Q. (2015). The impacts of firework burning at the Chinese Spring Festival on air quality: Insights of tracers, source evolution and aging processes. Atmos. Chem. Phys. 15: 2167-2184.

Li, L., Yin, Y., Kong, S., Wen, B., Chen, K., Yuan, L. and Li, Q. (2014). Altitudinal effect to the size distribution of water soluble inorganic ions in PM at Huangshan, China. Atmos. Environ. 98: 242-252.

Li, Z.Q., Niu, F., Fan, J.W., Liu, Y.G., Rosenfeld, D. and Ding, Y.N. (2011). Long-term impacts of aerosols on the vertical development of clouds and precipitation. Nat. Geosci. 4: 888-894.

Lin, W., Mao, Y.Q. and Liu, D.Q. (2012). The characteristics and relationship with meteorological elements of haze weather in nearly 3 years in Nanjing. $J$. Nanyang I. Tech. 4: 76-80. (in Chinese)

Malm, W.C. and Day, D.E. (2001). Estimates of aerosol species scattering characteristics as a function of relative humidity. Atmos. Environ. 35: 2845-2860.

Malm, W.C., Sisler, J.F., Huffman, D., Eldred, R.A. and Cahill, T.A. (1994). Spatial and seasonal trends in particle concentration and optical extinction in the United States. J. Geophys. Res. 99: 1347-1370.

MEP (2012). Chinese ministry of environmental protection. Ambient air quality standards (GB 3095-2012), 2012. http://kjs.mep.gov.cn/hjbhbzbzwb/dqhjbh/dqhjzlbz/20120 3/W020120410330232398521.pdf, Last Access: 5 August 2015.

Qi, B., Hu, D., Che, H., Du, R., Wu, Y., Xia, X., Zha, B., Liu, J., Niu, Y., Wang, H., Zhang, X and Shi, G. (2016). Seasonal variation of aerosol optical properties in an urban site of the Yangtze Delta Region of China. Aerosol Air Qual. Res. 16: 2884-2896.

Qian, L., Yin, Y., Dong, Y.Q., Wang, W.W. and Wei, Y.X. (2008). Characteristics of size distributions of atmospheric fine particles in the north suburban area of Nanjing. China Environ. Sci. 28: 18-22. (in Chinese)

Ramanathan, V., Crutzen, P.J., Kiehl, J.T. and Rosenfeld, D. (2001). Aerosols, climate, and hydrological cycle. Science 7: 2119-2124.

Sandradewi, J., Prévôt, A.S., Szidat, S., Perron, N., Alfarra, M.R., Lanz, V.A., Weingartner, E. and Baltensperger, U. (2008). Using aerosol light absorption measurements for the quantitative determination of wood burning and traffic emission contributions to particulate matter. Environ. Sci. Technol. 42: 3316-23.

Shen, X.J., Sun, J.Y., Zhang, X.Y., Zhang, Y.M., Zhang, L., Che, H.C., Ma, Q.L., Yu, X.M., Yue, Y. and Zhang, Y.W. (2015). Characterization of submicron aerosols and effect on visibility during a severe haze-fog episode 
in Yangtze River Delta, China. Atmos. Environ. 120: 307-316.

Shen, Z., Cao, J., Arimoto, R., Han, Z., Zhang, R., Han, Y., Liu, S., Okuda, T., Nakao, S. and Tanaka, S. (2009). Ionic composition of TSP and $\mathrm{PM}_{2.5}$ during dust storms and air pollution episodes at Xi'an, China. Atmos. Environ. 43: 2911-2918.

Sherman, J.P., Sheridan, P.J., Ogren, J.A., Andrews, E., Hageman, D., Schmeisser, L., Jefferson, A. and Sharma, S. (2015). A multi-year study of lower tropospheric aerosol variability and systematic relationships from four North American regions. Atmos. Chem. Phys. 15: 12487-12517.

Singh, T., Khillare, P.S., Shridhar, V. and Agarwal, T. (2008). Visibility impairing aerosols in the urban atmosphere of Delhi. Environ. Monit. Assess. 141: 6777.

Tan, J.H., Duan, J.C., Chen, D.H., Wang, X.H., Guo, S.J., Bi, X.H., Sheng, G., He, K. and Fu, J. (2009). Chemical characteristics of haze during summer and winter in Guangzhou. Atmos. Res. 94: 238-245.

Tian, L., Zhang, W. Shi, J.S., Huang, J.P., Song, S.T., Ding, X.D., Bi, J.R., Cao, X.J. and Zhang, L. (2010). A preliminary study on scattering property of dust aerosol in Hexi Corridor. Plateau Meteorol. 29: 1050-1057. (in Chinese)

Tian, P., Wang, G., Zhang, R., Wu, Y. and Yan, P. (2015). Impacts of aerosol chemical compositions on optical properties in urban Beijing, China. Particuology 18: 155-164.

Turpin, B.J. and Lim, H.J. (2001). Species contributions to $\mathrm{PM}_{2.5}$ mass concentrations: Revisiting common assumptions for estimating organic mass. Aerosol Sci. Technol. 35: 602-610.

US EPA (1999). Particulate matter $\left(P M_{2.5}\right)$ speciation guidance document (Third draft), U.S. Environmental Protection Agency, USA, p. 69.

US EPA (2013). U. S. 40 CFR Parts 50, 51, 52, 53, and 58National Ambient Air Quality Standards for Particulate Matter: Final Rule. Fed. Regist. 78: 3086-3286.

Wang, H., Zhu, B., Shen, L., Xu, H., Pan, Y., Li, Y. and Liu, D. (2016). Regional characteristics of air pollutants during heavy haze events in the Yangtze River Delta, China. Aerosol Air Qual. Res. 16: 2159-2171.

Wang, H.L., An, J.L., Shen, L.J., Zhu, B., Pan, C., Liu, Z., Liu, X., Duan, Q., Liu, X. and Wang, Y. (2014). Mechanism for the formation and microphysical characteristics of submicron aerosol during heavy haze pollution episode in the Yangtze River Delta, China. Sci. Total Environ. 490: 501-508.

Wang, Q., Cao, J., Tao, J., Li, N., Su, X., Chen, L.A., Wang, P., Shen, Z., Liu, S. and Dai, W. (2013). Longterm trends in visibility and at Chengdu, China. PLoS One 8: e68894.

Wang, T. (2003). Study of visibility and its causes in Hong Kong, Final Report to the Environmental Protection Department of Hong Kong, Ref. AS01-286.

Wang, Y.H., Liu, Z.R., Zhang, J.K., Hu, B., Ji, D.S., Yu, Y.C. and Wang, Y.S. (2015). Aerosol physicochemical properties and implications for visibility during an intense haze episode during winter in Beijing. Atmos. Chem. Phys. 15: 3205-3215.

Wei, F.F., Liu, H., Lu, X.B., Wang, Q.G., Ge, Y. and Hao, J. (2017). Temporal and spatial characteristics of secondary components of $\mathrm{PM}_{2.5}$ in Nanjing. China Environ. Sci. 37: 2866-2876. (in Chinese)

Weingartner, E., Saathoff, H., Schnaiter, M., Streit, N., Bitnar, B. and Baltensperger, U. (2003). Absorption of light by soot particles: Determination of the absorption coefficients by means of aethalometers. J. Aerosol Sci. 34: $1445-1463$.

WHO (2006). Air quality guidelines: Global update 2005: Particulate matter, ozone, nitrogen dioxide and sulfur dioxide. World Health Organization, Regional Office for Europe, Denmark.

Wiscombe, W.J. and Grams, G. (1976). The backscattered fraction in two-stream approximations. J. Atmos. Sci. 33: 2440-2451.

Xu, X.F., Qiu, J.H., Xia, X.A., Sun, L. and Min, M. (2015). Characteristics of atmospheric aerosol optical depth variation in China during 1993-2012. Atmos. Environ. 119: 82-94.

Yan, P., Pan, X., Tang, J., Zhou, X., Zhang, R. and Zeng, L. (2009). Hygroscopic growth of aerosol scattering coefficient: A comparative analysis between urban and suburban sites at winter in Beijing. Particuology 7: 5260.

Ye, Z.L., Liu, J.S., Gu, A.J., Feng, F.F., Liu, Y.H., Bi, C.L., Xu, J.Z., Li, L., Chen, H., Chen, Y.F., Dai, L., Zhou, Q.F. and Ge, X.L. (2017). Chemical characterization of fine particulate matter in Changzhou, China, and source apportionment with offline aerosol mass spectrometry. Atmos. Chem. Phys. 17: 1-46.

Yu, X.N., Ma, J., An, J.L., Yuan, L., Zhu, B., Liu, D., Wang, J., Yang, Y. and Cui, H. (2016a). Impacts of meteorological condition and aerosol chemical compositions on visibility impairment in Nanjing, China. J. Cleaner Prod. 131: 112-120.

Yu, X.N., Ma, J., Kumar, K.R., Zhu, B., An, J.L., He, J.Q. and Li, M. (2016b). Measurement and analysis of surface aerosol optical properties over urban Nanjing in the Chinese Yangtze River Delta. Sci. Total Environ. 542: 277-291.

Zhang, T. (2010). Research on size distribution and chemical composition of fine particles and their impact on visibility in urban Guangzhou. Master, Jinan University, China.

Zhang, T., Chillrud, S.N., Ji, J., Chen, Y., Pitiranggon, M., Li, W., Liu, Z. and Yan, B. (2017). Comparison of $\mathrm{PM}_{2.5}$ exposure in hazy and non-hazy days in Nanjing, China. Aerosol Air Qual. Res. 17: 2235-2246.

Zhang, W., Hu, B., Chen, C., Du, P., Zhang, L. and Feng, G. (2004). Scattering properties of atmospheric aerosols over Lanzhou city and applications using an integrating nephelometer. Adv. Atmos. Sci. 21: 848-856.

Zhang, Y., Yin, Y., Xiao, H., Kuang, S.S. and Wu, Z.H. (2012). An observation study of the scattering properties of aerosols over Shijiazhuang City in spring. China 
Environ. Sci. 32: 769-779.

Zhao, X., Zhang, X., Pu, W., Meng, W. and Xu, X. (2011). Scattering properties of the atmospheric aerosol in Beijing, China. Atmos. Res. 101: 799-808.

Zhou, M.G., Liu, Y.N., Wang, L.J., Kuang, X.Y., Xu, X.H. and Kan, H.D. (2014). Particulate air pollution and mortality in a cohort of Chinese men. Environ. Pollut. 186: $1-6$.

Zhu, C.S., Cao, J.J., Hu, T.F., Shen, Z.X, Tie, X.X., Huang,
H., Wang, Q.Y., Huang, R.J., Zhao, Z.Z., Močnik, G. and Hansen, A. (2017). Spectral dependence of aerosol light absorption at an urban and a remote site over the Tibetan Plateau. Sci. Total Environ. 590-591: 14-21.

Received for review, December 29, 2017 Revised, April 19, 2018 Accepted, April 19, 2018 